\title{
Accurate mapping of Arctic glaciers over 50 years ago
}

\author{
JoHN WRIGHT \\ Webbs Farmhouse, Cakeham Road, West Wittering, Chichester, West Sussex PO20 8LG, England
}

\begin{abstract}
This paper will describe what it was like to map Arctic glaciers starting 62 years ago in Iceland; then in Nordaustland, Svalbard, in 1935-36; and finally in northwest Greenland and Ellesmere Island, Northwest Territories, Canada, in 1937-38. The glacier in Iceland was resurveyed by a party including me in 1992; and I made a less successful attempt to resurvey the Greenland glacier in 1993.
\end{abstract}

\section{HISTORIGAL BACKGROUND}

As this Conference is celebrating 50 years of glacier investigations, this paper will try to give an idea of what work in the Arctic once used to be like, when no air photographs were available, nor helicopters, nor the electronics for distance measurement, global fixing, recording or computation. All the fieldwork had to be carried out on foot, using for longer journeys boats in the summer and dog sledges in the spring and early summer.

Also, although we obtained grants and instruments from our universities and scientific societies, these only covered our expenses; except for personnel seconded from the armed services, we were not paid any salaries for the work. Some were helped by their parents, and newspaper articles and lectures paid for the rest.

\section{TRAVEL AND SURVEY}

After World War I, British scientists planning work in the polar regions realised that the age of long, fast journeys discovering new lands was over. What was now required was intensive investigation of relatively small areas, with surveys producing contoured maps showing coastlines and glacier fronts accurate to better than $1 \mathrm{~km}$. This involved much slower travel, usually laying deposits beforehand, and not relying on Eskimo or hunting for food. We operated in two- or three-man parties doing every thing ourselves, including boat

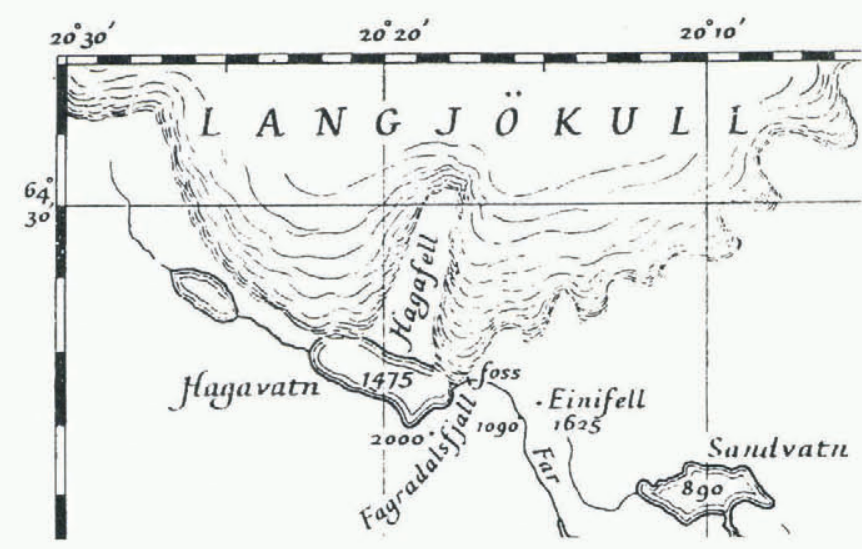

Fig. 1. Hagavatn, southwest Iceland (Reynolds, 1930). management, dog-driving, camping, cooking, and carrying the survey equipment, which had to be as light as possible, up to our survey stations. In the spring we worked on windy hilltops in temperatures as low as $-30^{\circ} \mathrm{C}$, so the work had to be done as simply and quickly as possible (Wright, 1939a).

Existing maps were often very inaccurate, as shown in Figures 1 and 2 (Reynolds, 1930; Wright 1940). In Ellesmere Island, for example, the mountains inland were marked as running north and south and $2000 \mathrm{ft}(600 \mathrm{~m})$ high; in fact they ran east and west and were $6000 \mathrm{ft}(1800 \mathrm{~m})$ high. In Iceland, larger-scale mapping only reached the southern shore of Hagavatn, and only 1:500000 scale maps existed further north. Nordaustland, Svalbard, had been better investigated, particularly along its western section where a

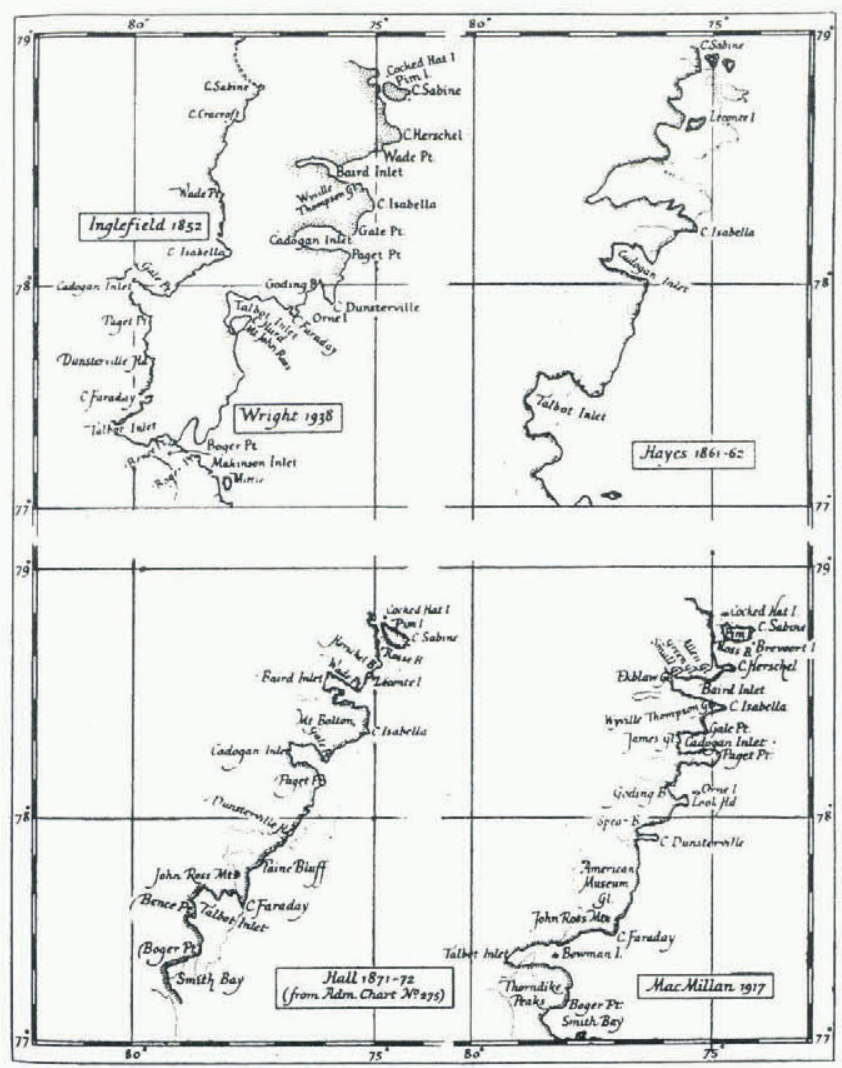

Fig. 2. Southeast Ellesmere Island, Northwest Territories, Canada (Wright, 1940). 


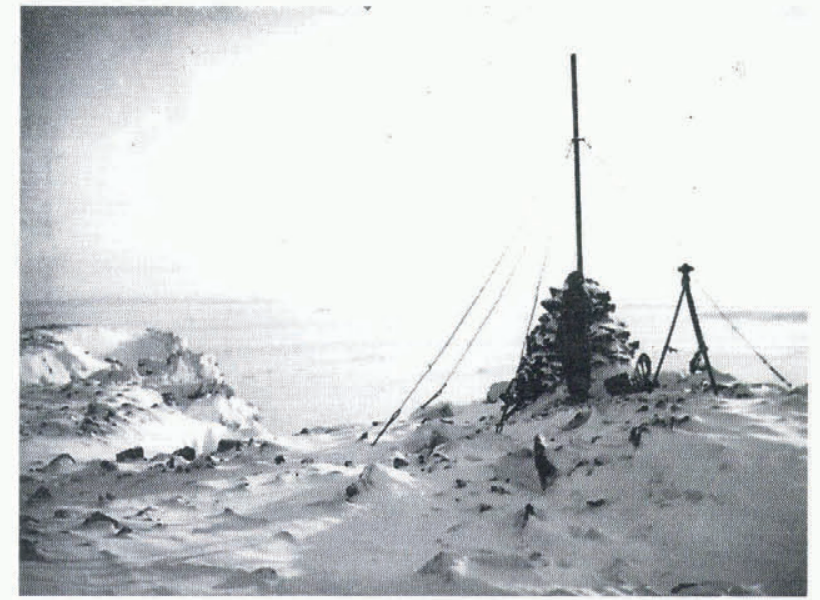

Fig. 3. Remains of the Russo-Swedish beacon at Extreme Hook, Nordaustland, 1935.

Russo-Swedish expedition had measured a polar arc of meridian, to be compared with an equatorial one in Peru, to establish the shape of the Earth. They mapped the area, including South Franklin Glacier (Moss and Glen, 1939).

In Iceland we mapped both Hagavatn and its two glaciers at 1:20000 scale with $25 \mathrm{~m}$ contours, and a $25 \mathrm{~km}$ length of the ice-cap edge to the west at 1:100000 with $100 \mathrm{~m}$ contours (Wright, 1935). In Nordaustland we ran a rough triangulation starting from the Russo-Swedish arc (Fig. 3), with detail surveyed by plane table at 1:100000 and 1:250000 scale (Wright, 1940). However, with bad weather delaying work on the spring journey, a faster technique had to be used for the final eastern section; and shortbase theodolite fixing was accompanied by detail sketching from hand-held photographs.

Because the area could be traversed only once, and cairns built after occupying a survey station, the forward rays of the triangulation had to be taken to boulders or other natural marks on the hilltops (Fig. 4), and triangles closed to l' $^{\prime}$ or so of arc. Positions of the triangulation had to be computed in the field for the plane tabler, using logarithms and adding these by hand, since not even adding machines were available. However, later analysis showed that over its $150 \mathrm{~km}$ length the survey was accurate to about $30 \mathrm{~m}$, and it was, I believe, relied on for later Norwegian surveys of the area.

On returning to Cambridge in 1936 I met Michael Spender, who had invented a new, more accurate and much faster detail technique which he used on a Mount Everest reconnaissance and with the Danish Government surveys in East Greenland. This was to mount an ordinary good camera on a table fixed to the theodolite so that the camera axis was horizontal and parallel to that of the theodolite telescope (Wright, 1939a; Wright and Dahl, 1995).

This had two major advantages. First, one was able to compare photographs from different survey stations at leisure in a warm room at home, instead of relying for identifying detail, at a second or third survey station, on sketches drawn in cold conditions at an earlier one. This resulted in at least five times as many common points being identified, such as dirt cones on glaciers, and snow or rock patches on mountainsides as well as peaks. The second advantage over hand-held or even separately levelled photographs was that one could then measure horizontal and vertical angles to these points from the photographs, and thus supplement the few taken with the theodolite. Detailed survey and contouring was then possible.

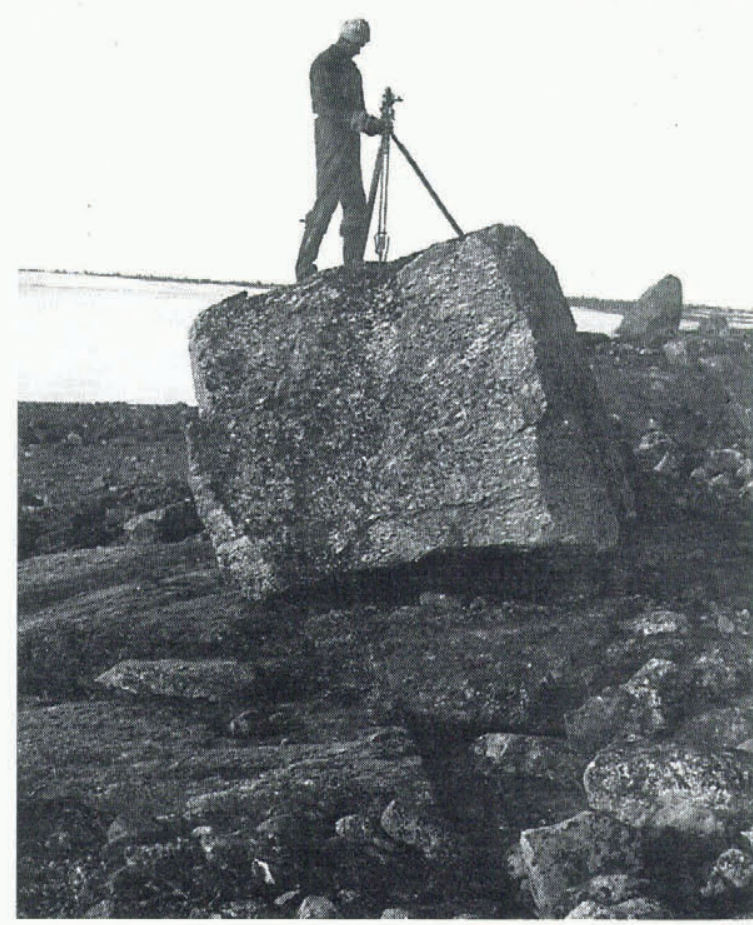

Fig. 4. Using theodolite, with shortened tripod, on boulder in Nordaustland, 1936.

In those days, in our case at least, these detail points were plotted graphically. After one had plotted all the survey-station positions and theodolite intersections, one set out from these the directions of the photographs taken from each station, usually at $30^{\circ}$ intervals. A line representing the photograph would then be drawn at right-angles to the end of each ray, at a distance equal to the equivalent focal length of the enlargements. This would be determined by comparison of the rays to a number of points intersected by theodolite included in one photograph, with their distances along the horizon line from the principal point of the photograph. These distances were transferred to the plot with a pair of dividers.

The principal point was defined on the photograph by the intersection of the horizon and vertical lines drawn through collimating marks; and on the plot by the intersection of the ray and perpendicular line representing it. Other points identifiable on at least two photographs taken from different survey stations could then have rays drawn through them and be intersected. Heights were obtained from each photograph by measuring the vertical distances from the horizon line on it and deriving the vertical angles from these.

Thus, working afterwards in comfort at home, one operated like a plane tabler using intersection (including heighting) only. Angle accuracies were about $10^{\prime}$ of arc, or $3 \mathrm{~m}$ in height at $1 \mathrm{~km}$. However, as was proved in our 1992 resurvey of the Hagavatn glacier, using modern computers and analytical photogrammetry, much higher accuracies, of about $1^{\prime}$ of arc or $1 \mathrm{~m}$ in height at $3 \mathrm{~km}$, can be achieved. This is more precise than is obtainable with the air photography normally available in such areas, or from satellite imagery.

Strangely, although this photographic technique was described by Spender and myself in well-known journals before World War II, only one other expedition, and our 1992 Iceland one, seem to have used it since. In trying to 
account for this failure to use a cheap, quick and safe way of surveying glaciers, I have concluded that, since today people doing this work get government, academic or media grants, elaborate and expensive electronic or aerial techniques may be more attractive for that reason.

So much for the details; how did the technique work in practice? In Iceland none of us had used a theodolite, so we measured a base and triangulated graphically with the plane table. In Nordaustland we extended at a much lower standard the Russo-Swedish Survey, and we used the same rough triangulation in northwest Greenland (Wright, 1939b), measuring a base. But in Ellesmere Island there was no control available, so we had to rely on astronomical observations, supplemented by a rough triangulation connecting the major peaks, plotted graphically at home.

In April and May at that latitude, the sun was up continually, and, fortunately for us, shining most of the time. Other, cleverer surveyors have, I believe, managed to compute beforehand the positions of a few bright stars and find them with the theodolite, but I could not do this, so we relied on sun observations. The disadvantage of these is that each observation gives only a position line; one had to wait several hours to get a fix.

We overcame this with what I believe was an original technique. Most of our survey stations were on hilltops, and we camped in sight of these on the sea ice or ice cap below. We set out at the camp a short base marked by two ski poles, and then observed the bearing to this and the subtended angle from the survey station, thus obtaining their relative positions. Then, as sea or air navigators use dead reckoning to combine two position lines, we could include all sun shots taken at either the camp or the station to fix the latter. Quite often we obtained four shots in $24 \mathrm{~h}$, including two on the meridian, with a position accuracy of under $0.5 \mathrm{~km}$.

As a result of using these techniques, and with excellent weather, the survey of southeastern Ellesmere Island carried out by my companion Richard Hamilton (Fig. 5) and myself in April and May 1938 covered $10000 \mathrm{~km}^{2}$ at a plotting scale of 1:200000 with $100 \mathrm{~m}$ contours. Hamilton recorded times with a deck watch kept always against his chest to maintain it at a constant temperature, and this was checked against radio time signals (Wright, 1940).

I believe that this survey may well be unique in its combination of extent and accuracy, given the minimal manpower involved, the high latitude of the survey site and the fact that the survey was carried out 58 years ago. It remained the best, indeed the only, map of the area until the Canadian Government carried out a major operation, including aerial photography, in 1959.

One disadvantage of a spring survey was that all the land was covered in snow, though crevassed glaciers were easily defined; and this accounts for some of the differences between the two maps. I had hoped to map some of the glaciers as they were in 1938 at a larger scale with closer contours, using copies of the photographs, observations and the original plot from the Scott Polar Research Institute, Cambridge (Wright and Dahl, 1995, p. 46-47). However, because of the poor quality of the exposures, and subsequent erasure of the plotted construction lines, this has proved too difficult even with my knowledge of the project.

One more technique of detail survey with a theodolite is worth mentioning. This is to survey a coastline overlooked by high peaks by depression angles from them, using their

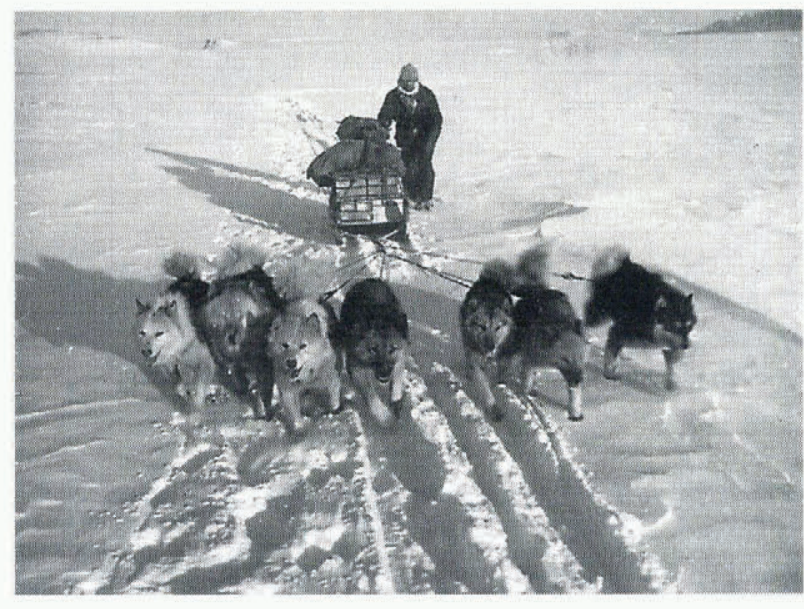

Fig. 5. R. Hamilton driving dog sledge in Ellesmere Island in 1938.

measured heights above sea level as the bases of vertical rangefinders. This technique was, I believe, first used by Dr John Ball on the rugged Red Sea coast of Egypt. We found it invaluable both in Nordaustland and in Greenland and Ellesmere Island. A sketch was drawn of the coastline seen from the survey station, whose height had already been determined, and points were then picked out on this at 2 or $3 \mathrm{~km}$ intervals.

The observer would then point the theodolite telescope at each of these points in turn, recording the horizontal and vertical angles on one face only. In this way, from the $436 \mathrm{~m}$ high Mount Louise Richard in the middle of Dove Bay, Nordaustland, two of us mapped some $60 \mathrm{~km}$ of its intricate southern coastline in about 2 hours: a lot quicker and more accurate than running a compass traverse along it!

For this work, and other short-base techniques used for identifying features intersected by theodolite, and also for the astronomical observations, a one-second instrument was of course essential. In Nordaustland we had British Watts theodolites with two microscopes for reading each of the two circles; this meant moving round the instrument to read the angles, which was not always easy on some survey stations (Fig. 4).

However, in Greenland and Ellesmere Island we were very lucky to be able to borrow from the Royal Geographical Society (RGS) the unique (in those days) Wild T2 onesecond theodolite which had just been returned from the Antarctic. I owed much to the Secretary, Arthur Hinks, for both letting me have this and allowing it to have the platform fitted for the camera as already described. One great advantage of this instrument was that readings were taken using a small telescope alongside the main one, thus saving movement round it. The other was that it matched the graduations on both sides of the circles, and thus combined observations of these in one operation. This made observations in low temperatures very much easier and quicker, especially as we had to take off the tripod leg extensions to lighten it, and I had sometimes to observe on my knees.

\section{RESULTS}

\section{(1) Iceland}

The results of our work in these four areas have been fully described in the papers published at the time (Reynolds, 
1930; Wright, 1935), but a brief account follows. In Iceland we were investigating a major flood which had occurred in 1929 when East Hagafell Glacier damming Hagavatn had burst and the lake dropped $10 \mathrm{~m}$, releasing some $50 \times 10^{-6} \mathrm{~m}^{3}$ of water in a few hours. No one was there; but the resulting flood washed away a bridge and the farmers' crops downstream.

It also cut a $0.5 \mathrm{~km}$ long, $60 \mathrm{~m}$ deep gorge creating the beautiful waterfall Leynifoss. Two Englishmen and some Icelanders visited the area but did no scientific work, nor were they able to photograph the new waterfall. As it happened, we were the only people who published a photograph.

In 1933 my attention was drawn to this problem by Dr Brian Roberts, and three of us from Cambridge University spent 6 weeks there in 1934, mapping the lake and area, measuring the water flow in and out, and sounding the lake. I predicted at an RGS meeting in 1935 that, assuming continuation of the glacial cycles which had occurred previously, there would not be another flood for 30 years. However, with global warming, the glacier went on retreating; only 4 years later it caused another flood. It had uncovered a lower exit to the north, so the lake dropped another $10 \mathrm{~m}$, dried out its shallow southern half and created a second, though less spectacular, gorge and waterfall, with the first left dry except for some springs.

No further investigation was possible until after World War II, but the position of the glacier front has been recorded many times since (Fig. 6). However, surveys made by expeditions at the time of its furthest retreat, in 1967 (by Shirebrook School, U.K.: unpublished information from T. Grey, 1968), and of its furthest advance in 1979-81 (unpublished information from University of Durham, U.K., 1981) have not been published. Oddly, by far the best map, at 1:20000 scale with $20 \mathrm{~m}$ contours, made by the Iceland National Power Company in 1963 from air photos taken in 1960, was not published or known to any of these expeditions. In 1992 the Survey Department map at 1:50 000 was the latest available, from air photos taken in 1985 with $25 \mathrm{~m}$ contours. A preliminary comparison with our 1992 survey indicates that the front part of the glacier has melted down by some $30 \mathrm{~m}$ since then. There is a ridge some $10 \mathrm{~km}$ further back and the glacier front seems to accumulate behind this, and then surge over it, a fairly common sequence.

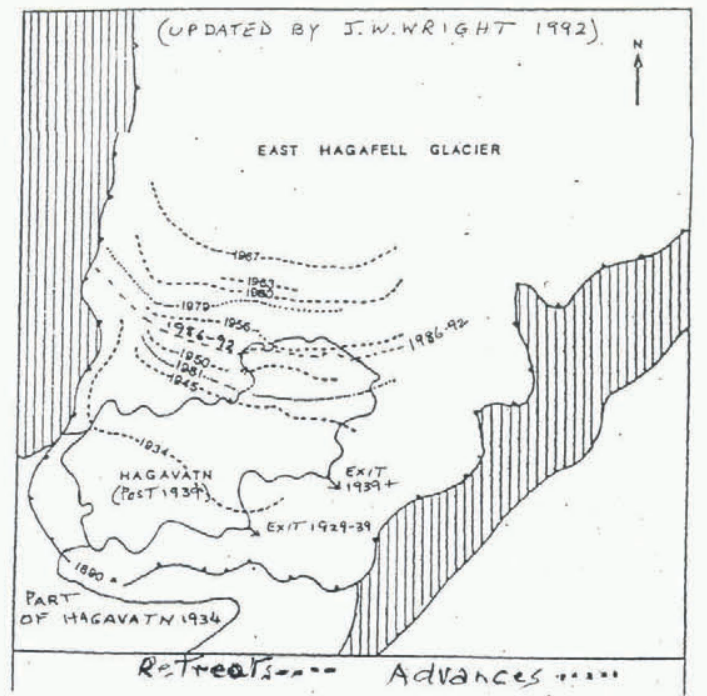

Fig. 6. Ice-front positions of East Hagafell Glacier, southwest Iceland, 1890-1981 (unpublished information from University of Durham, 1981; updated by author, 1992).

\section{(2) Nordaustland}

Thanks to the Russo-Swedish expedition already mentioned, and G. Binney's 1924 expedition, we have a good early record of South Franklin Glacier in the northwestern corner of Nordaustland (Moss and Glen, 1939). Its frontal position was surveyed in 1901, 1924 and 1936, showing a retreat of about $3 \mathrm{~km}$ in 35 years. I have not had access to satellite imagery or later surveys of the north coast; but these may well show significant changes in other glaciers further east. Glen and Croft surveyed by compass traverse the eastern and southern coasts (Glen 1937; Glen and Croft, 1937). There have been several investigations of the surging of the eastern ice cap since 1938; and it may well be that N. Nordenskjöld's experience of huge troughs or "canals" when crossing this ice cap in 1873 was due to a surge at that time of its eastern front.

\section{(3) Greenland}

\section{(a) Moltke Glacier}

This $7 \mathrm{~km}$ wide, $30 \mathrm{~km}$ long glacier comes straight out of the Greenland ice cap (lat. $76^{\circ} 30^{\prime} \mathrm{N}$ ); and since its front has been surveyed at intervals since 1916, it is a useful indicator of the state of this part of the ice cap. We mapped it in 1937, and checked its flow during the year by comparing survey photographs taken in September 1937 and August 1938 (Wright, 1939c). It was mapped from air photographs by the Americans (Mock, 1966), and, I believe, by the Danes from 1985 air photographs. I tried to survey it in 1993, but had not realised that while the U.S. airbase staff would help me get to a point overlooking the glacier, they were not going to camp. Being on my own for two days, fortunately in wonderful weather, I was only able, at the age of 79 and over very rough ground, to establish safely two photo stations $400 \mathrm{~m}$ apart and was unable to make a photogrammetric survey from such a short base.

However, I was able to establish that its front had scarcely moved since 1985 , with a total retreat during the previous 77 years of about $8 \mathrm{~km}$ (Fig. 7). This high-latitude glacier is surely worth a more detailed investigation now, including soundings of the fjord over which it had previously lain, and I strongly recommend it as a project for a small party. Since the end of the Cold War the USAF base $30 \mathrm{~km}$ to the west has been open to any visitors, and it is visited regularly by commercial aircraft. In addition, the harbour has several months of open water in the summer, so heavy equipment could be sent up by ship. Danish contractors work there during the summer as the 2 mile $(3 \mathrm{~km})$ long runway has a 4 year programme of maintenance. Thus, it is at least as accessible as glaciers on the east coast of Greenland which have been thoroughly investigated; I hope someone will take up this challenge, and would be happy to advise anyone interested.

\section{(b) Greenland ice cap}

After our return from Ellesmere Island at the end of May 1938 I found that Ike Schlossbach, a well-known American aviator working with the MacGregor meteorological expedition based at Etah, northwest Greenland, claimed to have seen bare land east of Etah. He was flying alone over clouds, and later agreed that what he had seen was the land between the glaciers at the head of Inglefield Gulf. His aircraft had been damaged while being freed from the winter 


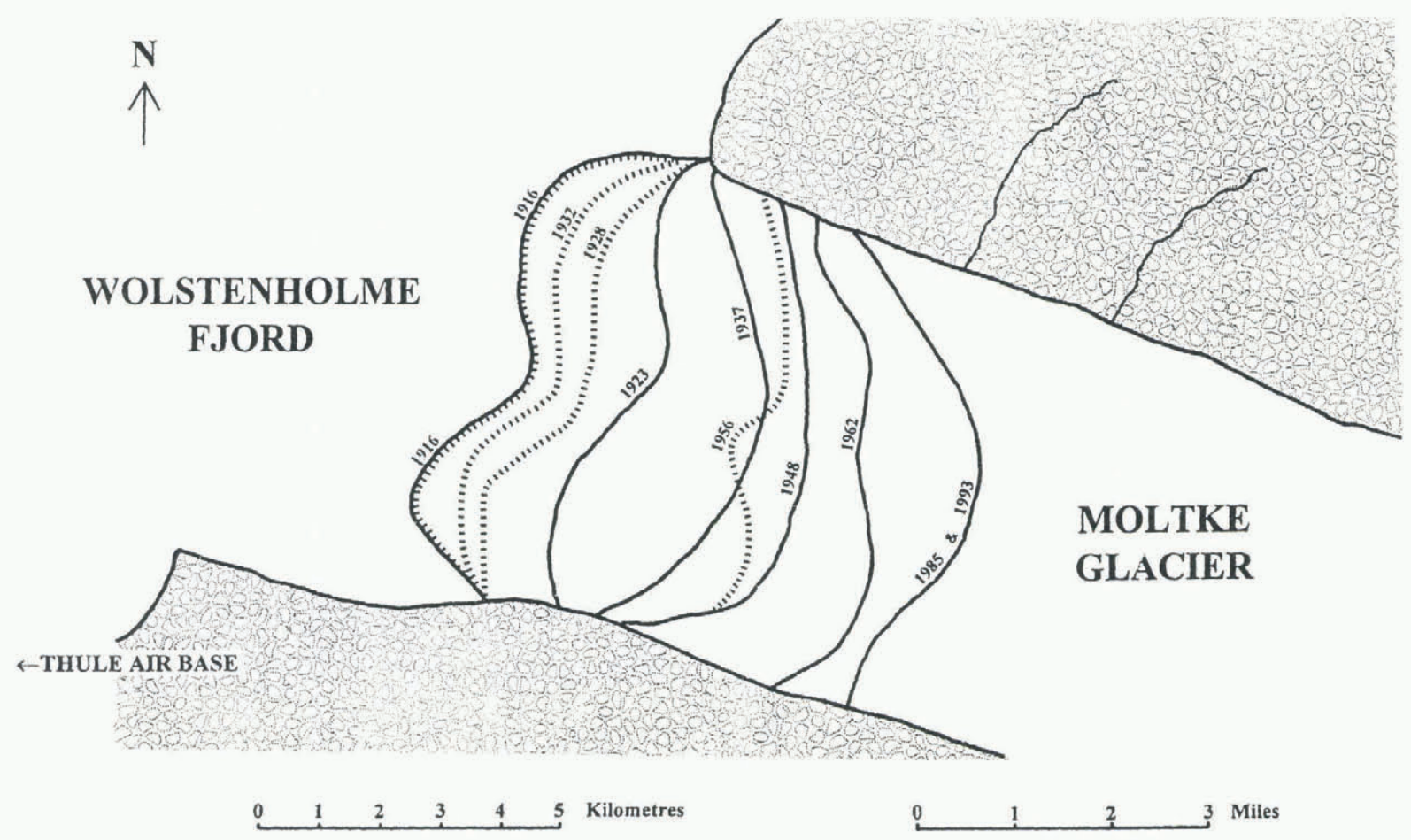

Fig. 7. Changes in Moltke Glacier, near Thule, northwest Greenland (lat. $76^{\circ} 30^{\prime}$ N ), 1916-93.

snow, so instead of repeating his flight with me as navigator, he agreed to accompany me on a $500 \mathrm{~km}$ traverse of the ice cap to look for this nunatak, using my sledge and dogs.

We found, as I expected, that it did not exist. But thanks to the excellent barometric record at Etah, and to very settled weather, we ran a barometric traverse which the British Meteorological Department estimated to have measured heights accurate to about $30 \mathrm{~m}$. Their checks included a rerun in a vacuum chamber of my having re-set my barometer on reaching, and returning to, $1500 \mathrm{~m}$ because of its limited range and the unexpectedly high nature of the ice cap.

Although our map was published in Denmark (Wright, 1939c), no notice of our altimetry has been taken in the 1:5000000 scale maps of Greenland published at various dates up to 1982 by the Danish Geodetic Institute; nor have they corrected the $15 \mathrm{~km}$ error which I found in the edge of the ice cap as mapped by Lauge Koch many years earlier by, as he freely admitted, much rougher methods of survey and without a radio set to check his longitudes. Satellite radar heights appear to confirm our results (Massom, 1995).

\section{(4) Ellesmere Island}

Comparison with the 1967 Canadian 1:250 000 map indicates that the large Talbot and Cadogan Glaciers had retreated by 8 and $5 \mathrm{~km}$, respectively, in the 21 years between our 1938 survey and the Canadian aerial photography taken in 1959 for the 1967 Canadian 1:250,000 map. C. S. L. Ommanney (personal communication, 1994) has told me of earlier aerial photography which can be found in the Canadian archives. More precise measurements of these and later changes since our early surveys could be made by others - and perhaps have been - using satellite imagery, radar or new aerial photography. However, I have no details of these.

\section{CONCLUSION}

Whatever plans may be made for future surveys of these glaciers, especially by those with limited finances, I hope that this Conference will at least draw attention to the cheap, quick and safe technique pioneered by Spender and adapted by Hamilton and myself. As has been shown by our 1992 Iceland survey using modern photogrammetric techniques, it would still be more accurate for measuring heights, and thus glacier volumes, than satellite imagery or small-scale aerial photography. I hope it will not be forgotten.

\section{REFERENGES}

Glen, A. R. 1937. The Oxford University Arctic Expedition, North East Land, 1935-36. Geogr. 7., 90 (3 \& 4), 193 -232/289-314.

Glen, A. R. and N. A. C. Croft. 1937. Under the Pole Star. London, Methuen.

Massom, R. A. 1995. Satellite remote sensing of polar snow and ice: present status and future directions. Polar Rec., 31 (177), 99-114.

Mock, S. J. 1966. Fluctuations of the terminus of the Moltke Glacier. CRREL Tech. Rep. 179.

Moss, R. and A. R. Glen. 1939. The retreat of the South Franklin Glacier, North East Land. Geogr. 7., 93(3), 228-229.

Reynolds, J. H. 1930. Burst of glacial dam in Iceland. Geogr. J., 75 (3), $241-243$.

Wright, J.W. 1935. The Hagavatn gorge, Geogr. 7., 86(3), 218-234.

Wright, John. 1939a. Survey on polar expeditions. Polar Rec., 18, 144-168.

Wright, J.W. 1939b. Contributions to the glaciology of north-west Greenland. Medd. Grenl., 125(3), 442.

Wright, J.W. 1939c. Methods of survey in North East Land. Geogr. 7., 95(4), 280-291.

Wright, J.W. 1940. Southeast Ellesmere Island. Geogr. 7., 95(4), 278-291.

Wright, J.W. and P. A. Dahl. 1995. A cheap, quick and safe way of surveying glaciers. Photogram. Rec., 15(85), 43-50. 